\title{
PENGARUH SISTEM OLAH TANAH DAN WAKTU PENYIANGAN PADA HASIL TANAMAN JAGUNG (Zea mays $L$.)
}

\author{
Muhamad Noor Azizu \\ Program Studi Agroteknologi, \\ Fakultas Pertanian dan Peternakan \\ Universitas Muslim Buton \\ e-mail: muhamad.noor.azizu@gmail.com
}

\begin{abstract}
The presence of disturbing plants in the cultivation process of corn plants will respond to the corn crop yields. The presence of disturbing plants can cause competition in the photosynthesis process. In essence, weed control is to suppress the population. The purpose of this study was to examine the effects of tillage patterns and time of weeding on maize crop products and to obtain a combination of tillage patterns with appropriate weeding times for corn planting. The experiment was conducted from February to June 2020 at the Buton UMU Research Experimental Garden. Laboratory analysis was carried out in the integrated laboratory of the Faculty of Agriculture and Animal Husbandry of UMU Buton. The experiment was arranged in a split-plot design (RPT) with three replication. main plots were tillage system consists of three levels., (1) T1 = zero tillage; (2) T2 = minimal tillage; and (3) $T 3=$ maximum tillage. Subplots were a time of weeding consists of four levels., (1) P1 = no weeding; (2) $P 2=$ weeding 21 days after planting; (3) P3 = weeding 21 and 42 days after planting; and (4) P4 = weeding 21, 42 and 63 day after planting. The results showed that the appropriate combination of T1 and T4 treatment would produce better maize/plant weight and corn seed yields of 6.27 tonnes $\mathrm{ha}^{-1}$, whereas for $T 2$ and $\mathrm{T} 3$ it did not require weeding time with yields respectively maize harvest was 5.84 tonnes ha-1 and 5.83 tonnes $\mathrm{ha}^{-1}$.
\end{abstract}

Keywords: Conservation, weeds, maize

\begin{abstract}
Abstrak
Kehadiran tanaman penggangu pada proses budidaya tanaman jagung akan memberikan respon pada hasil panen tanaman jagung. Keberadaan tanaman penggangu dapat menyebabkan persaingan pada proses fotosintesis. Pada intinya, pengendalian gulma ialah menekan populasinya. Tujuan dari penelitian ini adalah untuk menguji efek dari pola olah tanah dengan waktu penyiangan pada produk panen tanaman jagung dan untuk mendapatkan gabungan pola olah tanah dengan waktu penyiangan yang tepat pada penanaman jagung. Penelitian dilaksanakan pada bulan Februari hingga Juni 2020 di Kebun percoban penelitian kampus UMU Buton. Analisa laboratorium dilaksanakan di laboratorium terpadu fakultas Pertanian dan Peternakan UMU Buton. Rancangan yang digunakan pada penelitian ini ialah rancangan petak terbagi (RPT) dengan tiga ulangan. Sistem olah tanah sebagai petak utama, yang terdiri atas tiga taraf, yaitu : (1) T1 = Tidak ada olah tanah; (2) T2 = Olah tanah
\end{abstract}




\section{P-ISSN: $2527-8479$ E-ISSN: 2686-2174}

minimal; dan (3) T3 = Olah tanah maksimal. Anak petak ialah waktu penyiangan, yang terdiri atas 4 taraf, yaitu : (1) P1 = Tanpa penyiangan; (2) P2 = Penyiangan 21 hst; (3) P3 = Penyiangan 21 dan 42 hst; dan (4) P4 = Penyiangan 21, 42 dan 63 hst. Hasil penelitian menunjukkan bahwa Kombinasi yang sesuai pada perlakuan T1 dengan T4 akan menghasilkan berat biji/ tanaman jagung dan hasil biji tanaman jagung 6,27 ton ha $^{-1}$ yang lebih baik, sedangkan untuk T2 dan T3 tidak membutuhkan waktu penyiangan dengan masing-masing mendapatkan hasil panen jagung sebesar 5,84 ton ha $\mathrm{han}^{-1}$ da,83 ton ha ${ }^{-1}$.

Kata kunci: konservasi, gulma, jagung

\section{PENDAHULUAN}

\section{Latar Belakang}

Pengolahan tanah dan persaingan dengan gulma adalah beberapa msaalah dalam budidaya tanaman jagung. Mekanisme pengolahan tanah seringkali tidak berhasil dalam menekan jumlah gulma. Hal ini terjadi karena proses pengolahan tanah dapat menyebabkan terjadinya bagian-bagian vegetatif gulma tersebar, seperti rhizon, stolon dan akar. Pengolahan tanah konvensional adalah salah satu sistem pengolahan tanah yang umum digunakan meskipun banyak petani juga menggunakan sistem pengolahan tanah konservasi atau tanpa pengolahan. Pengolahan tanah konvensional adalah proses penyiapan lahan yang menggunakan peralatan pengolahan tanah seperti bajak atau cangkul untuk mengemburkan tanah dan memasukkan bahan tanam sebagai bagian dari persiapan persemaian. Manipulasi mekanis tanah mempengaruhi sifat tanah, evapotranspirasi (ET), dan produksi tanaman (Busari et al., 2015). Membajak permukaan tanah meningkatkan porositas tanah dan mengubur sisa tanaman, pupuk kandang, dan menekan pertumbuhan gulma. Namun, pengolahan tanah konvensional menyebabkan peningkatan erosi tanah dan hilangnya karbon organik tanah, stabilitas agregat, dan kelembaban (West dan Marland, 2002). Oleh karena itu, sangat penting untuk menerapkan pengolahan tanah konservasi seperti tanah tegakan atau pengolahan tanah yang dikurangi untuk produksi pertanian yang berkelanjutan. Sistem pertanian konservasi telah diadopsi diberbagai wilayah iklim dunia (Liu et al., 2013; Marandola et al., 2019). Namun, penelitian menunjukkan hasil yang beragam mengenai dampak pengolahan lahan konservasi pada tanah dan sumber daya air. Penerapan pengolahan tanah konservasi telah terbukti mengurangi erosi tanah dengan meningkatkan residu 


\section{P-ISSN: $2527-8479$ E-ISSN: 2686-2174}

permukaan (Wagle et al., 2018). West dan Post (2002) menunjukkan bahwa praktek budidaya yang intensif dapat mengurangi hilangnya karbon organik tanah. Penelitian lain menunjukkan kandungan air tanah yang lebih tinggi dalam pengolahan lahan konservasi dibandingkan dengan sistem pengolahan tanah konvensional (Asmamaw, 2016; Liu et al., 2013; Moriasi et al., 2012).

Pengendalian gulma dengan waktu penyiangan merupakan pengendalian secara fisik. Tanaman jagung akan memberikan hasil terbaik, apabila memperhatikan periode kritis tanaman seperti waktu penyiangan. Periode $1 / 4$ sampai dengan 1/3 umut tanaman merupakan periode kritis tanaman semusim. Hasil penelitian Ferrell et al., (2012) bahwa gulma dapat mengurangi hasil panen jagung, yang disebabkan adanya kompetesi dalam merebutkan nutrisi, kelembaban dan cahaya selama masa pertumbuhan. Menurut Moenandir (2010) bahwa persaingan tanaman dengan gulma pada periode kritis dapat menurunkan hasil panen sebesar 60\%. Berdasarkan pernyataan dari Hendrival et al., (2014) bahwa gulma yang tumbuh pada lahan pertanian harus dilakukan pengecekan dan pengendalian gulma agar memeperoleh kualitas maupun kuantitas produksi secara maksimal.

Sistem tanpa pengolahan tanah atau konservasi dan waktu penyiangan adalah hal-hal yang dapat dilakukan petani dalam menyelesaikan permasalahn budidaya tanaman jagung. Kombinasi dari tanpa olah tanah dan penambahan waktu penyiangan merupakan kegiatan untuk mencegah kerusakan tanah dengan menjaga temperatur tanah, mengurangi erosi tanah, tanah dapat menyerap air dengan maksimal dan mencegah pertumbuhan gulma. Hasil penelitian Steiner et al., (2015) bahwa pengolahan lahan konservasi telah direkomendasikan untuk meningkatkan infiltrasi dan kandungan air tanah, dan mengurangi penguapan, suhu tanah, dan erosi, selain itu, pengolahan tanah konservasi dapat menambah bahan organik, membangun kesuburan tanah; (Franzluebbers, 2010) meminimalkan emisi gas rumah kaca dan mempertahankan gulma yang masih dorman di dalam tanah. Sedangkan pengendalian gulma dengan waktu penyiangan tidak membutuhkan biaya yang besar dibandingkan dengan pengendalian menggunkan herbisida dan olah tanah maksimal. Untuk dapat menekan pertumbuhan gulma, petani dapat meningkatkan kegiatan penyiangan yaitu 21, 42 dan 63 hst. Oleh karena itu, salah satu alternatif yang diharapkan untuk mengendalikan gulma adalah kombinasi antara sistem olah tanah dan waktu penyiangan. 


\section{P-ISSN: 2527-8479 E-ISSN: 2686-2174}

\section{Tujuan}

1. Untuk menguji efek dari pola olah tanah dengan waktu penyiangan pada produk panen tanaman jagung.

2. Untuk mendapatkan gabungan pola olah tanah dengan waktu penyiangan yang tepat pada penanaman jagung.

\section{METODE PENELITIAN}

\section{Waktu Penelitian dan Tempat}

Kegiatan penelitian ini dilaksanakan pada bulan Februari hingga Juni 2020 di Kebun percoban penelitian kampus UMU Buton. Analisa laboratorium dilaksanakan di laboratorium terpadu fakultas Pertanian dan Peternakan UMU Buton.

\section{Alat dan Bahan}

Timbangan analitik, pengaris, jangka sorong, oven dan kamera merupakan alat yang digunakan selama penelitian. Sedangkan benih jagung varietas pioner 21, herbisida Amexone $500 \mathrm{SC}$ (herbisida berbahan aktif ametrin), Urea (dosis $200 \mathrm{~kg} \mathrm{ha}^{-1}$ ), $\mathrm{SP}_{36}\left(\right.$ dosis $75 \mathrm{~kg} \mathrm{ha}^{-1}$ ) dan $\mathrm{KCl}$ (dosis $50 \mathrm{~kg} \mathrm{ha}^{-1}$ ) merupakan bahan yang digunakan selama penelitian.

\section{Metode penelitian}

Rancangan petak terbagi (RPT) dengan tiga ulangan digunakan dalam metode penelitian ini. Pola olah tanah sebagai petak utama, dilakukan dengan tiga fase, yaitu : (1) T1 = Tidak ada olah tanah; (2) T2 = Olah tanah minimal; dan (3) T3 = Olah tanah maksimal. Waktu penyiangan sebagai anak petak, dilakukan dengan empat fase, yaitu : (1) P1 = Tanpa penyiangan; (2) P2 = Penyiangan 21 hst; (3) P3 = Penyiangan 21 dan 42 hst; dan (4) P4 = Penyiangan 21, 42 dan 63 hst.

\section{Pelaksanakan}

\section{Persiapan Lahan}

Persiapan lahan dilakukan sebagai berikut:

1. 36 petak disiapkan untuk jumlah perlakuan. 


\section{Media Agribisnis}

Vol. 4, Issue 2, November 2020

\section{P-ISSN: 2527-8479 E-ISSN: 2686-2174}

2. Setiap petak dibuat berukuran $230 \times 190 \mathrm{~cm}$, dan dilanjutkan dengan perlakuan $\mathrm{T} 1, \mathrm{~T} 2 \mathrm{dn} \mathrm{T} 3$.

3. Tidak ada pembajakan dan mencangkulan pada perlakuan T1 hanya disemprot herbisida dengan bahan aktif ametrin. T2 dilaksanakan dengan cara tanah hanya cangkul satu kali. Sedangkan T3 dilaksanakan dengan 2 kali pembalikan tanah menggunakan cangkul, pada interval 1 minggu antara pengolahan pertama dan kedua.

\section{Penamanan}

Jagung ditanam dengan sistem tugal sedalam $3 \mathrm{~cm}$ dengan jumlah 2 benih jagung perlubang, pada jarak adalah $70 \times 30 \mathrm{~cm}$.

\section{Perlakuan Waktu Penyiangan}

Penyiangan menggunakan sabit (mekanik) dan waktunya sesuai perlakukan P1, P2, P3 dan P4.

\section{Proses Budidaya Tanaman Jagung}

Proses budidaya tanaman jagung meliputi :

1. Penanaman ulang bagi tanaman jagung yang tidak tumbuh, sedangkan untuk yang tumbuh lebih dari 1 dilakukan pengurangan.

2. Proses pemberian pupuk sesuai waktu dan dosis

3. Penggenangan air pada fase-fase krisis air

4. Pengangana OPT

\section{Panen}

Umur panen tanaman jagung adalah 96 hst dengan kondisi kelobot jagung berwarna kekuningan dan tongkol jagung telah berisi penuh.

\section{Pengamatan}

Pengamatan yang dilakukan pada komponen hasil adalah tongkol jagung dan biji jagung. Tongkol jagung antara lain; panjang tongkol jagung, diameter tongkol jagung, berat kering tongkol jagung yang berkelobot dan berat kering tongkol jagung yang tidak kelobot. Pengamatan hasil biji jagung meliputi bobot biji/ tongkol, bobot 100 biji dan pipilan kering dalam ton $\mathrm{ha}^{-1}$. 


\section{Media Agribisnis}

Vol. 4, Issue 2, November 2020

\section{P-ISSN: 2527-8479 E-ISSN: 2686-2174}

Pengamatan dalam penelitian meliputi :

1. Diameter tongkol jagung $(\mathrm{cm})$, yang diukur adalah bagian ujung tongkol jagung, bagian tengah dan bagian pangkal tongkol jagung.

2. Panjang tongkol jagung $(\mathrm{cm})$, diukur dengan cara meletakan penggaris dari pangkal tongkol sampai dengan pucuk tongkol jagung. Bobot tongkol kering (gram),

\section{Analisis Data}

Analisa data dilakukan dengan menggunakan uji $\mathrm{F}$ pada taraf nyata $5 \%$. Jika terjadi perbedaan yang nyata antar perlakuan, maka dilanjutkan uji BNT taraf $5 \%$.

\section{Hasil}

Pada fase vegetatif tanaman dapat mempengaruhi komponen hasil tanaman. Sedangkan kondisi fase vegetatif tanaman yang baik, akan memperoleh biji jagung yang baikpula. Pengamatan yang dilakukan pada komponen hasil adalah tongkol jagung dan biji jagung. Pengamatan tongkol jagung yaitu; panjang tongkol jagung, diameter tongkol jagung, berat kering tongkol jagung yang berkelobot dan berat kering tongkol jagung yang tidak kelobot. Hasil biji jagung yang diamati yaitu berat biji/ tongkol, berat 100 biji dan pipilan kering dalam ton $\mathrm{ha}^{-1}$.

\section{Tongkol Jagung}

\subsection{Panjang dan Diameter Tongkol Jagung yang tidak berkelobot $(\mathrm{cm})$}

Panjang dan diameter tongkol jagung yang tidak berkelobot pada uji statistik menunjukkan bahwa tidak terjadi interaksi antar perlakuan. Rerata pada perlakuan pola olah tanah dan waktu penyiangan ditampilkan dalam tabel 1.

Tabel 1. Rerata panjang tongkol jagung yang tidak berkelobot dan diameter tongkol jagung yang tidak berkelobot pada perlakuan sistem olah tanah dan waktu penyiangan.

\begin{tabular}{|c|c|c|}
\hline Perlakuan & $\begin{array}{c}\text { Diameter tongkol jagung } \\
\text { yang tidak berkelobot }\end{array}$ & $\begin{array}{l}\text { Panjang tongkol jagung } \\
\text { yang tidak berkelobot }\end{array}$ \\
\hline & $\cdots$ & ... \\
\hline \multicolumn{3}{|c|}{ Sistem Olah Tanah : } \\
\hline $\mathrm{T} 1$ & $5,24 \mathrm{~b}$ & $19,99 \mathrm{~b}$ \\
\hline $\mathrm{T} 2$ & $4,99 \mathrm{a}$ & $18,14 \mathrm{a}$ \\
\hline $\mathrm{T} 3$ & $4,98 \mathrm{a}$ & $18,37 \mathrm{a}$ \\
\hline BNT $5 \%$ & 0,192 & 0,736 \\
\hline
\end{tabular}




\section{P-ISSN: 2527-8479 E-ISSN: 2686-2174}

\begin{tabular}{lcc}
\hline Waktu Penyiangan : & \\
P1 & 5,17 & $18,09 \mathrm{a}$ \\
P2 & 5,04 & $18,64 \mathrm{ab}$ \\
P3 & 5,10 & $18,97 \mathrm{~b}$ \\
P4 & 5,06 & $19,62 \mathrm{~b}$ \\
\hline BNT 5\% & tn & 0,748 \\
\hline
\end{tabular}

Keterangan : tn = tidak ada perbedaan antar perlakukan; adanya huruf yang sama pada samping angka menunjukkan tidak berbeda nyata pada uji BNT 5\%.

Tabel 1 menunjukkan bahwa P1 menghasilkan panjang tongkol jagung yang tidak berkelobot dan diameter tongkol jagung yang tidak berkelobot lebih besar dibandingkan perlakukan P2 dan P3. Sedangkan perlakuan P4 menghasilkan panjang tongkol jagung yang tidak berkelobot lebih besar $(19,62)$ dibandingkan P1, P2, dan P3.

\subsection{Bobot Kering Jagung Berkelobot dan Tanpa Berkelobot (gram)}

Tabel 2. Rerata berat kering jagung yang tidak berkelobot dan bobot kering jagung yang memiliki kelobot pada perlakuan sistem olah tanah dan waktu penyiangan.

\begin{tabular}{ccc}
\hline Perlakuan & $\begin{array}{c}\text { Berat kering jagung yang } \\
\text { tidak berkelobot }\end{array}$ & $\begin{array}{c}\text { Berat kering jagung yang } \\
\text { memiliki kelobot }\end{array}$ \\
\hline
\end{tabular}

Sistem Olah Tanah :

gram

$\begin{array}{lrr}\text { T1 } & 178,48 & 194,06 \\ \text { T2 } & 175,35 & 191,86 \\ \text { T3 } & 158,23 & 186,93\end{array}$

\begin{tabular}{lcc}
\hline BNT 5\% & tn & tn \\
\hline Waktu Penyiangan : & $146,45 \mathrm{a}$ & $187,75 \mathrm{a}$ \\
P1 & $180,23 \mathrm{~b}$ & $179,03 \mathrm{a}$ \\
P2 & $187,07 \mathrm{~b}$ & $197,45 \mathrm{~b}$ \\
P3 & $168,99 \mathrm{ab}$ & $199,56 \mathrm{~b}$ \\
P4 & 27,29 & 14,52 \\
\hline BNT 5\% & a & 158,93 \\
\hline
\end{tabular}

Keterangan : tn = tidak ada perbedaan antar perlakukan; adanya huruf yang sama pada samping angka menunjukkan tidak berbeda nyata pada uji BNT $5 \%$.

Berat kering jagung yang tidak kelobot perlakuan sistem olah tanah tidak terdapat perbedaan yang nyata. Perlakuan P3 menghasilkan berat kering jagung yang tidak berkelobot lebih besar dengan peningkatakn sebesar $21,71 \%$ dibandingkan P1, namun tidak terdapat perbedaan yang nyata pada perlakukan P2 dan P3. 


\section{Media Agribisnis}

\section{Vol. 4, Issue 2, November 2020}

\section{P-ISSN: $2527-8479$ E-ISSN: 2686-2174}

Berat kering jagung yang memiliki kelobot pada perlakuan sistem olah tanah tidak terdapat perbedaan yang nyata. Perlakuan P4 menghasilkan berat kering jagung yang memiliki kelobot lebih besar dengan peningkatan sebesar 10,28\% dibandingkan P1 dan P2, namun tidak terdapat perberbeda yang nyata pada perlakuan P3.

\section{Biji Jagung}

\subsection{Berat Biji/Tanaman Jagung (gram)}

Parameter berat biji/tanaman jagung menunjukkan bahwa terdapat adanya interaksi antara sistem olah tanah dengan waktu penyiangan. Tabel 3 menunjukkan rerata pada perlakuan.

Tabel 3. Rerata berat biji/tanaman jagung (gram) terdapat adanya interaksi antara perlakuan sistem olah tanah dengan waktu penyiangan.

\begin{tabular}{|c|c|c|c|c|}
\hline \multirow{2}{*}{ Sistem Olah Tanah } & \multicolumn{4}{|c|}{ Waktu Penyiangan } \\
\hline & P1 & P2 & P3 & P4 \\
\hline & & $\ldots \ldots \ldots$ & & \\
\hline $\mathrm{T} 1$ & $144,44 \mathrm{a}$ & $145,78 \mathrm{ab}$ & $151,00 \mathrm{c}$ & $154,92 \mathrm{~d}$ \\
\hline $\mathrm{T} 2$ & $144,21 \mathrm{ab}$ & $142,44 \mathrm{ab}$ & $145,88 \mathrm{ab}$ & $146,89 \mathrm{~b}$ \\
\hline T3 & $144,04 \mathrm{ab}$ & $145,16 \mathrm{ab}$ & $146,78 \mathrm{~b}$ & $146,61 \mathrm{~b}$ \\
\hline
\end{tabular}

Keterangan : Adanya huruf yang sama pada samping angka menunjukkan tidak berbeda nyata pada uji BNT $5 \%$.

Interaksi yang terjadi antara perlakuan $\mathrm{T} 1$ dengan $\mathrm{P} 4$ menghasilkan berat biji/tanaman jagung lebih besar dibandingakan dengan T2 dan T3. Begitupula dengan perlakuna P1, P2 dan P3.

\subsection{Biji Jagung (Ton ha ${ }^{-1}$ )}

Parameter berat biji jagung (Ton ha ${ }^{-1}$ ) menunjukkan bahwa terdapat adanya interaksi antara sistem olah tanah dengan waktu penyiangan. Tabel 4 menunjukkan rerata pada perlakuan.

Tabel 4. Rerata hasil biji (ton $\mathrm{ha}^{-1}$ ) terdapat adanya interaksi antara perlakuan sistem olah tanah dengan waktu penyiangan.

\begin{tabular}{llrrr}
\hline \multirow{2}{*}{ Sistem Olah Tanah } & \multicolumn{3}{c}{ Waktu Penyiangan } \\
\end{tabular}




\section{P-ISSN: $2527-8479$ E-ISSN: 2686-2174}

\begin{tabular}{|c|c|c|c|c|}
\hline \multirow[b]{2}{*}{$\mathrm{T} 1$} & \multicolumn{3}{|c|}{.. ton $\mathrm{ha}^{-1}$} & \multirow[b]{2}{*}{$6,27 \mathrm{~d}$} \\
\hline & $5,85 \mathrm{ab}$ & $5,90 \mathrm{ab}$ & $6,11 \mathrm{c}$ & \\
\hline $\mathrm{T} 2$ & $5,84 \mathrm{ab}$ & $5,77 \mathrm{a}$ & $5,90 a b$ & $5,95 \mathrm{~b}$ \\
\hline T3 & $5,83 \mathrm{ab}$ & $5,88 \mathrm{ab}$ & $5,94 \mathrm{~b}$ & $5,93 \mathrm{~b}$ \\
\hline
\end{tabular}

Keterangan : Adanya huruf yang sama pada samping angka menunjukkan tidak berbeda nyata pada uji BNT $5 \%$.

Perlakuan T1 dengan P4 menghasilkan hasil biji (ton ha ${ }^{-1}$ ) lebih besar dibandingkan T2 dan T3. Hasil yang sama pada berbagai taraf waktu penyiangan (P1, P2 dan P3).

Tabel 5. Rerata berat 100 biji jagung pada perlakuan sistem olah tanah dan waktu penyiangan.

\begin{tabular}{lc}
\hline Perlakuan & Berat 100 biji (gram) \\
\hline Sistem Olah Tanah : & 27,17 \\
T1 & 25,85 \\
T2 & 25,63 \\
T3 & tn \\
\hline BNT 5\% & \\
\hline Waktu Penyiangan & $24,78 \mathrm{a}$ \\
P1 & $25,80 \mathrm{~b}$ \\
P2 & $26,77 \mathrm{c}$ \\
P3 & $27,52 \mathrm{c}$ \\
P4 & 0,785 \\
\hline BNT 5\%
\end{tabular}

Keterangan : tn = tidak ada perbedaan antar perlakukan; adanya huruf yang sama pada samping angka menunjukkan tidak berbeda nyata pada uji BNT $5 \%$.

Tabel 5 menjelaskan bahwa perlakuan sistem olah tanah tidak berpengaruh nyata pada rerata berat 100 biji jagung. Sedangkan perlakuan P4 menghasilkan berat 100 biji lebih berat dengan peningkatan 9,95\% dan 6,25\% dibandingkan dengan $\mathrm{P} 1$ dan $\mathrm{P} 2$, namun tidak terdapat adanya berbeda yang nyata dengan P3.

\section{Pembahasan}

\section{Tongkol Jagung}

Penentuan hasil panen jagung dapat dipengaruhi oleh pertumbuhan tanamannya. Hasil penelitian menunjukkan sistem tanpa olah tanah memberikan diameter dan panjang tongkol jagung terbaik. Perlakuan sistem tanpa olah tanah menyebabkan biji gulma tetap berada 


\section{P-ISSN: 2527-8479 E-ISSN: 2686-2174}

didalam tanah. Kondisi biji gulma yang berada didalam tanah akan menyebabkan biji gulma tetap mengalami dormansi. Biji gulma yang tetap mengalamai dormansi didalam tanah, menyebabkan tanaman jagung tidak berkompetisi dengan gulma saat proses generatif awal. Selain mengurangi kompetesi gulma dengan tanaman jagung, perlakuan tanpa olah tanah atau konservasi dapat mengurangi erosi, penguapan, pencucian unsur hara maupu kehilangan abahan orgnaik. Vitale et al., (2011) menunjukkan bahwa 43,2\%, 26,7\%, dan 30,1\% dari luas Oklahoma di Amerika masing-masing ditutupi oleh konvensional, konservasi, dan pengolahan tanah yang dikurangi. Penerapan pengolahan lahan konservasi telah direkomendasikan untuk meningkatkan infiltrasi dan kandungan air tanah, dan mengurangi penguapan, suhu tanah, dan erosi (Steiner et al., 2015). Selain itu, pengolahan tanah konservasi dapat menambah bahan organik, membangun kesuburan tanah, dan meminimalkan emisi gas rumah kaca (Franzluebbers, 2010).

Tanaman jagung akan bersaing dengan gulma, apabila biji gulma yang terbenanm didalam tanah terangkat dan tumbuh. Tanaman penggangu yang tidak diharapkan tumbuh disekitar tanaman budidaya dapat menyebabkan penurunan hasil tanaman (Widaryanto, 2010). Hal ini dapat kita lihat pada hasil pengamatan tongkol jagung (Tabel 1). Hal ini diperkuat dengan penyataan dari Moenandir (2010) bahwa terangkatnya biji gulma yang berada didalam tanah dan tumbuh akan menjadi pesaing bagi tanaman budidaya.

Waktu penyiangan yang tepat untuk pada tanaman jagung yaitu 21 dan 42 hst dapat meningkatkan panjang tongkol, bobot kering jagung berkelobot dan tanpa kelobot. Ketepatan dalam pengendalian gulma sangat ditentukan oleh kerapatan dalam menentukan waktu pelaksanaan dan cara pengendalian gulma (Setiawan, 2014; Puspitasari et al., 2013; Sena et al., 2018). Produktivitas tanaman tidak tergangu, apabila gulma tidak tumbuh pada periode kritis. Salah satu cara mengurangi adanya kompetisi pada periode kriris, yaitu dengan melakukan penyiangan sebelumnya. Aplikasi waktu penyiangan yang lebih cepat dapat menekan jumlah pertumbuhan gulma, dan dapat mengurangi kehilangan hasil panen. Tanaman budidaya yang ditanam berdekatan dengan tanaman penggangu mampu menurunkan hasil tanaman jagung. Tanaman jagung yang ditanaman dan disekitarnya terdapat tanaman penggangu akan saling memberikan interaksi dan kompetisi. Interaksi tanaman jagung dengan gulma dalam perebutan cahaya, air dan unsur hara pada pada fase 


\section{P-ISSN: $2527-8479$ E-ISSN: 2686-2174}

vegetatif akan menghambat pertumbuhan tanaman dan mengurangi hasil panen (Puspitasari et al., 2013).

Tanaman penggangu atau biasa disebut gulma adalah tanaman yang dapat mengurangi hasil panen tanaman jagung. Penelitian dari (Nurlaili, 2010), bahwa kehilangan hasil panen yang disebabkan oleh serangan hama dan penyakit akan memberikan hasil panen yang sama dengan adanya tanaman penggangu disekitar tanaman budidaya. Faktor kunci yang menjadi penentu dalam produksi yang tinggi yaitu dengan pengendalian gulma yang tepat. Menurut Kastanja (2011) bahwa tumbuhnya gulma dapat menjadi penyebab salah satu rendahnya produksi suatu tanaman budidaya. Penanganan tanaman penggangu secara efisien dan efektif dapat menekan kehilangna hasil tanaman sebesar $50 \%$.

\section{Biji Jagung}

Interaksi pada perlakuan sistem olah tanah dengan waktu penyiangan pada komponen hasil. Pada berat biji/ tanaman jagung dan hasil biji tanaman jagung (ton ha ${ }^{-1}$ ), diperoleh kombinasi terbaik yaitu T1 dan T4. Kombinasi yang baik ini dapat menekan keberadaan gulma disekitar tanaman jagung, sehingga pertumbuhan vegetatif tidak tergangu. Hasil panen tanaman jagung dapat optimal, apabila pertumbuhan vegetatif tanaman tidak terganggu. Hal ini dapat terlihat pada berat kering tanaman penggangu yang rendah pada pertumbuhan tanaman jagung difase vegetatif yang baik.

Pertumbuhan vegetatif tanaman jagung yang baik akan membuat proses fotosintesis berjalan dengan baikpula. Biji jagung berasal dari cadangan makanan (karbohidrat) hasil fotosintesis pertumbuhan awal tanaman sampai dengan reproduksi. Proses fotosintesis yang baik akan mendorong terbentuknya biji yang maksimal. Hasil panen jagung yang baik diperoleh dari tanaman jagung yang ditanaman pada kondisi bebas tanaman penggangu dan dapat dijadikan standar budidaya. Penyataan tersebut diperkuat dengan hasil penelitian dari Dinata et al., (2012) bahwa penurunan proses fotosintesis akan menurunkan hasil tanaman jagung, yang disebabkan adanya kompetisi dengan tanaman penggangu. Faktor lingkungan akan mempengaruhi akumulasi asimilat dalam pembentukan biji jagung. Kastanja (2011), menyatakan bahwa pertumbuhan tanman jagung yang tidak baik, akan mempengaruhi $\mathrm{s}$ terbentuknya karbohidrat. 


\section{KESIMPULAN}

Kombinasi yang sesuai pada perlakuan T1 dengan T4 akan menghasilkan berat biji/ tanaman jagung dan hasil biji tanaman jagung 6,27 ton ha ${ }^{-1}$ yang lebih baik, sedangkan untuk T2 dan T3 tidak membutuhkan waktu penyiangan dengan masing-masing mendapatkan hasil panen jagung sebesar 5,84 ton ha ${ }^{-1}$ dan 5,83 ton ha ${ }^{-1}$.

\section{DAFTAR PUSTAKA}

Asmamaw, D.K. (2016). A Critical Review of the Water Balance and Agronomic Effects of Conservation Tillage Under Rain-fed Agriculture in Ethiopia. Land Degradation \& Development, 28, 843-855. https://doi:10.1002/ldr.2587.

Busari, M.A., Kukal, S.S., Kaur, A., Bhatt, R., \& Dulazi, A.A. (2015). Conservation Tillage Impacts on Soil, Crop and the Environment. International Soil and Water Conservation Research, 3, 119-129. https://doi:10.1016/j.iswcr.2015.05.002

Dinata, A., Sudiarso, \& Sebayang, H.T. (2017). Pengaruh Waktu dan Pengendalian Gulma Terhadap Pertumbuhan dan Hasil Tanaman Jagung (Zea mays L.). Jurnal Produksi Tanaman, 5 (2) : 191-197

Franzluebbers, A. (2010). Achieving Soil Organic Carbon Sequestration with Conservation Agricultural Systems in the Southeastern United States. Soil Sci. Soc. Am. J, 74, 347357. https://doi:10.2136/sssaj2009.0079.

Kastanja, A.Y. (2011). Identifikasi Jenis dan Dominansi Gulma pada Pertanaman Padi Gogo (Studi Kasus di Kecamatan Tobelo Barat, Kabupaten Halmahera Utara). Jurnal Agroforestri, 4 (1) : 40-46.

Liu, S., Zhang, X.-Y., Yang, J., \& Drury, C.F. (2013). Effect of Conservation and Conventional Tillage on Soil Water Storage, Water use Efficiency and Productivity of Corn and Soybean in Northeast China. Acta Agriculturae Scandinavica, Section B - Soil \& Plant Science, 63, 383-394. https://doi:10.1080/09064710.2012.762803.

Marandola, D., Belliggiano, A., R omagnoli, L., \& Ievoli, C. (2019). The Spread of No-Till in Conservation Agriculture Systems in Italy: Indications for Rural Development PolicyMaking. Agricultural and Food Economic, 7, 7. https://doi:10.1186/s40100-019-0126-8 


\section{P-ISSN: 2527-8479 E-ISSN: 2686-2174}

Moenandir, J. 2010. Persaingan Tanaman Budidaya dengan Gulma. Rajawali Press. Jakarta.

Moriasi, D.N., Arnold, J.G., Van Liew, M.W., Bingner, R.L., Harmel, R.D., \& Veith, T.L., (2007). Model Evaluation Guidelines for Systematic Quantification of Accuracy in Watershed Simulations. Transactions of the ASABE, 50 (3), 885-900. https://doi:10.13031/2013.23153.

Nurlaili. (2010). Respon Pertumbuhan Tanaman Jagung (Zea mays L.) dan Gulma Terhadap Berbagai Jarak Tanam. Agrobisnis, 2 (4) : 19-29.

Puspitasari, K., Sebayang, H.T., \& Guritno, B. (2013). Pengaruh Aplikasi Herbisida Ametrin dan 2,4-D dalam Mengendalikan Gulma Tanaman Tebu (Saccharum officinarum L.). Jurnal Produski Tanaman, 1 (2) : 72-80.

Sena, E. A., Sebayang, H.T., \& Nugroho, A. (2018). Pengaruh Waktu Penyiangan pada Tumpangsari Jagung (Zea mays L.) dan Kacang Tanah (Arachis hypogeae L.) Jurnal Produksi Tanaman, 6 (9) : 2085-2093.

Setiawan, D.P., A. S. Karyawati, A.S., \& Sebayang, H.T. (2014). Pengaruh Pengendalian Gulma pada Tumpangsari Ubi Kayu (Manihot esculenta) dengan Kacang Tanah (Arachis hypogaea L.). Jurnal Produksi Tanaman, 2 (3) : 239-246.

Steiner, J.L., Schneider, J.M., Pope, C., Pope, S., Ford, P., \& Steele, R.F. (2015). In: Anderson, T. (Ed.). United States Department of Agriculture, p. 61.

Vitale, J.D., Godsey, C., Edwards, J., \& Taylor, R. (2011). The Adoption of Conservation Tillage Practice in Oklahoma: Findings from a Producer Survey. Journal of Soil and Water Conservation, 66, 250-264. https://doi:10.2489/jswc.66.4.250

Wagle, P., Gowda, P.H., Northup, B.K., Turner, K.E., Neel, J.P.S., Manjunatha, P., \& Zhou, Y. (2018). Variability in Carbon Dioxide Fluxes Among Six Winter Wheat Paddocks Managed Under Different Tillage and Grazing Practices. Atmospheric Environment, 185, 100-108. https://doi:10.1016/j.atmosenv.2018.05.003.

West, T.O., \& Marland, G., (2002). A Synthesis of Carbon Sequestration, Carbon Emissions, and Net Carbon Flux in Agriculture: Comparing Tillage Practices in The United States. Agriculture, Ecosystems \& Environment. 91 (1-3), 217-232. https://doi:10.1016/S0167$\underline{8809(01) 00233-X .}$ 